\title{
sciendo
}

CIVIL AND ENVIRONMENTAL ENGINEERING REPORTS

E-ISSN 2450-8594

CEER 2019; 29 (3): 153-163

DOI: $10.2478 /$ ceer-2019-0031

Original Research Article

\section{DEFINING THE MATHEMATICAL DEPENDENCIES OF NOX AND CO EMISSION GENERATION AFTER BIOMASS COMBUSTION IN LOW-POWER BOILER}

\author{
Ladislav LUKÁČ ${ }^{1}$, Ján KIZEK ${ }^{1}$, Gustáv JABLONSKÝ1 ${ }^{1}$, \\ Yevgeniy KARAKASH ${ }^{2}$ \\ ${ }^{1}$ Technical university of Košice, Faculty of Materials, Metallurgy and Recycling, \\ Institute of Metallurgy, Letná 9, 04200 Košice, Slovak Republic \\ ${ }^{2}$ Department of Ecology, Heat Transfer and Labour Protection, National Metallurgical \\ Academy of Ukraine, Gagarine av. 4, Dnipro, Ukraine
}

\begin{abstract}
The paper deals with the study of the influence of various factors, which have an impact on emissions such as $\mathrm{NO}_{\mathrm{x}}, \mathrm{CO}$, which have been verified by measurements. Biomass in the form of wood chips as fuel of different moisture content from $9 \%$ to $25 \%$ has been tested at various boiler outputs. The presented work also defines the mathematical dependencies of $\mathrm{NO}_{\mathrm{x}}$ and $\mathrm{CO}$ emission generation by using regression analysis from measured data after biomass combustion in low-power boilers. The paper also describes a mathematical model of biomass combustion. The mathematical model was created to verify the measured data and prediction of emission generation in the process of biomass combustion. This model consists of combustion of stoichiometry, calculation of combustion temperatures, obtained regression equations of $\mathrm{NO}_{\mathrm{x}}$ and $\mathrm{CO}$. At the end of this paper, the obtained results are compared with the calculated models as well as the results of the defined dependencies from the regression analysis.
\end{abstract}

Keywords: wood chips combustion, emission generation, wood chips moisture content, mathematical dependence of emission

${ }^{1}$ Corresponding author: Technical university of Košice, Faculty of Materials, Metallurgy and Recycling, Institute of Metallurgy, Letná 9, 04200 Košice, Slovak Republic, e-mail: ladislav.lukac@tuke.sk,tel.+421556022407 


\section{INTRODUCTION}

The promotion activities include the energy policies and action plans of the EU member states in which they bound themselves to promote and implement certain levels of alternative energy sources for generation of heat and power, subsidies for companies and spreading the basic knowledge for the population of the EU so that they could learn more about these types of fuels and take active part in decreasing the emissions of the greenhouse gases and effects of utilization of fossil fuels on the environment.

Concern about depletion of fossil fuels, energy dependency and climate change have engendered the necessity to develop reliable, affordable and renewable energy sources like biomass fuels [1].

Using biomass as a fuel to substitute fossil fuels can reduce carbon emissions and can offer fuel security without the need to rely on imported fuel.

Different types of biomass have very different physical and chemical characteristics. The fuel properties and process conditions, such as fuel type, particle size, air flow rate and fuel moisture, affect the combustion characteristics, altering the heat generation, heat transfer and reaction rates in a complex manner [2-6].

The energy properties of fuelwood are crucially dependent on its moisture content, which adversely affects not only the basic energy properties, such as: higher heating value $\mathrm{Q}_{\mathrm{s}}$ and lower heating value $\mathrm{Q}_{\mathrm{n}}$, but also the process parameters of combustion in the furnace: flame temperature, generated amount of flue gases, the dew point of flue gases and emission production [7].

The quantity of gaseous emissions production depends on the amount of fuel supplied and its uniformity, the volume concentration of $\mathrm{O}_{2}$ and the relative humidity of the fuel. An important factor that significantly affects the amount of emissions produced is the fuel composition [8,9].

Experimental research and modelling of the fuel combustion processes can be used to clarify the formation of nitrogen oxides [10,11].

The application of experimental research of nitrogen oxides formation in practice should always lead to a reduction of these emissions.

The impact of the operation of biomass fired boilers on $\mathrm{NO}_{\mathrm{x}}$ and $\mathrm{CO}$ emissions is described by authors [12-15].

The control of this thermal aggregate is based on the determination of the necessary parameters, which are not always possible to determine directly. This problem was solved by authors in Ref. [16]. Differential equations of the heat conduction were applied in this work and a simulation model was created, which is the basis for indirect determination of temperatures in node points of the temperature field. 
In order to reliably determine the boiler output and improve the quality control of biomass combustion in an industrial biomass boiler, the calculation model based on online monitored boiler operation data has been successfully developed and tested by authors [17].

A CFD model was developed to predict gaseous emissions from combustion of biomass fuel and compared to diesel fuel in the furnace combustion chamber. Results showed that the quantity of emissions is closely related to the combustion temperature, molecular structure and fuel characteristics [1].

\section{MATERIALS AND METHODS}

The measurements were used to gather data of the predetermined parameters of wood chips at selected moisture contents and performance of the boiler. In order to obtain the necessary results three boiler thermal output of $50 \%, 75 \%$, and $100 \%$ as well as four different moisture content values of $9 \%, 14 \%, 19 \%$, and $25 \%$ were used.

\subsection{Equipment characteristics}

The type of boiler used for wood chips combustion experiment was HERZ firematic 80 with $83 \mathrm{~kW}$ of thermal output Fig. 1.

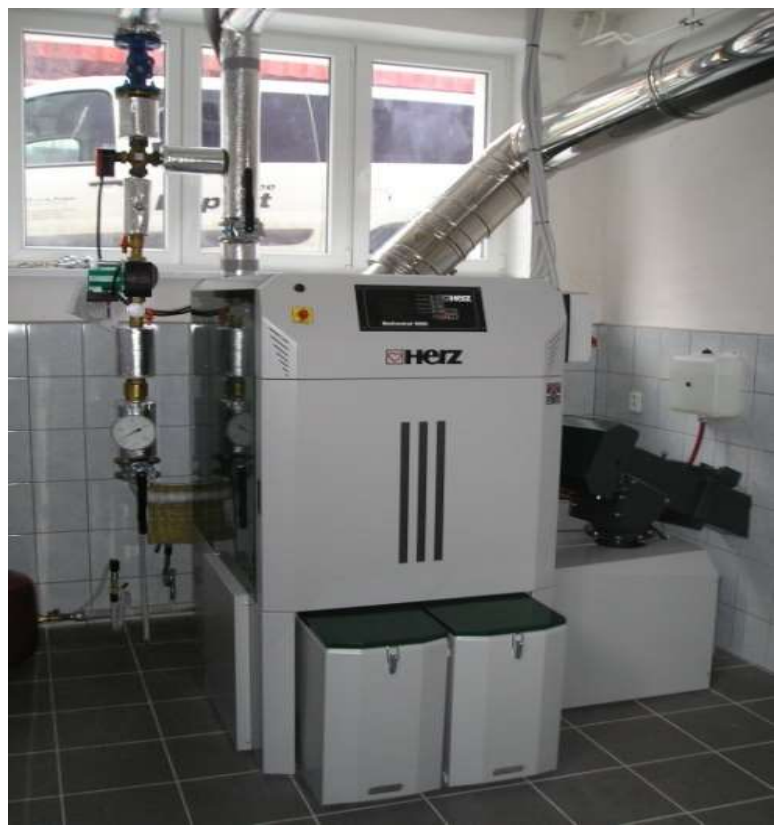

Fig. 1. HERZ firematic 80 
Emission gas concentrations were measured using the flue gas analyser Testo $300 \mathrm{M}$. The instrument can measure the flue gas temperature, ambient temperature, $\mathrm{O}_{2}, \mathrm{CO}_{2}, \mathrm{CO}, \mathrm{NO}_{\mathrm{x}}$, excess air and gross/net efficiency.

Moisture content measurement of the wood chips was realised exploiting the halogen analyser of moisture content Mettler Toledo HR83 shown in Fig. 2, operating on the thermo - gravimetric principle.

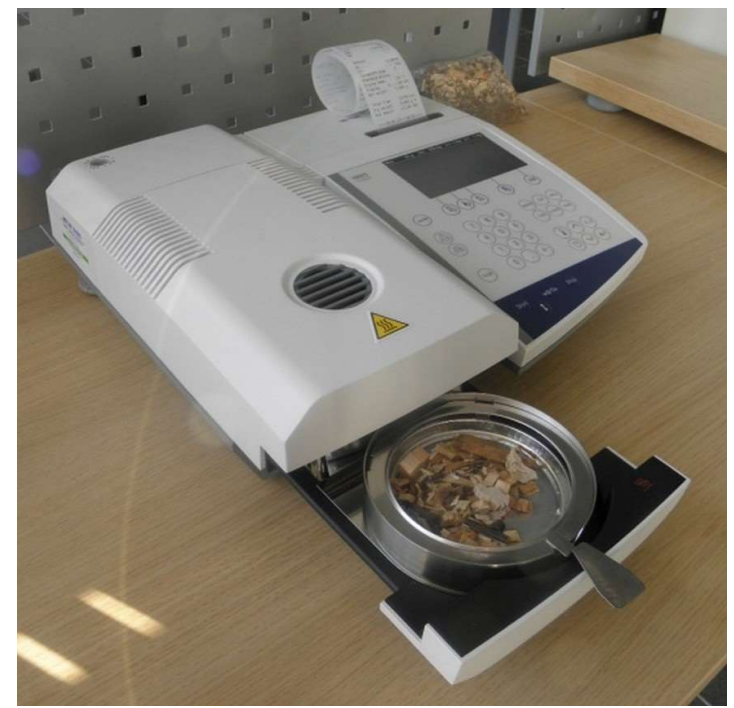

Fig. 2. Halogen analyser HR 83

\subsection{Mathematical model of combustion process}

Equations that were determined by regression analysis from the measured results are in the mathematical model also used for the calculation of $\mathrm{NO}_{\mathrm{x}}$ and $\mathrm{CO}$ emissions.

Calculations of the statics of fuel combustion are basis of thermal and technical calculations. The following thermal and technical parameters are determined at calculation of the statics of combustion [18]:

1. Calculation of the lower calorific value of the fuel,

2. Calculation of the minimum amount of oxygen, respectively the required for complete fuel combustion,

3. Calculation of the amount and composition of flue gases,

4. Calculation of physical properties of flue gases - (density, enthalpy, mean specific heat capacity),

5. Calculation of the adiabatic, theoretical and actual combustion temperature.

These calculations are included in the so-called statics of combustion. Kinetics of combustion discusses the time progression of the combustion. 


\section{Algorithm of mathematical model}

Based on the combustion stoichiometry the mathematical model was developed for the calculation of selected parameters of the solid fuel combustion process. The mathematical model consists of one main program, two subroutines for calculating the mean specific heat capacity of the combustion air and flue gas and the assistance data file.

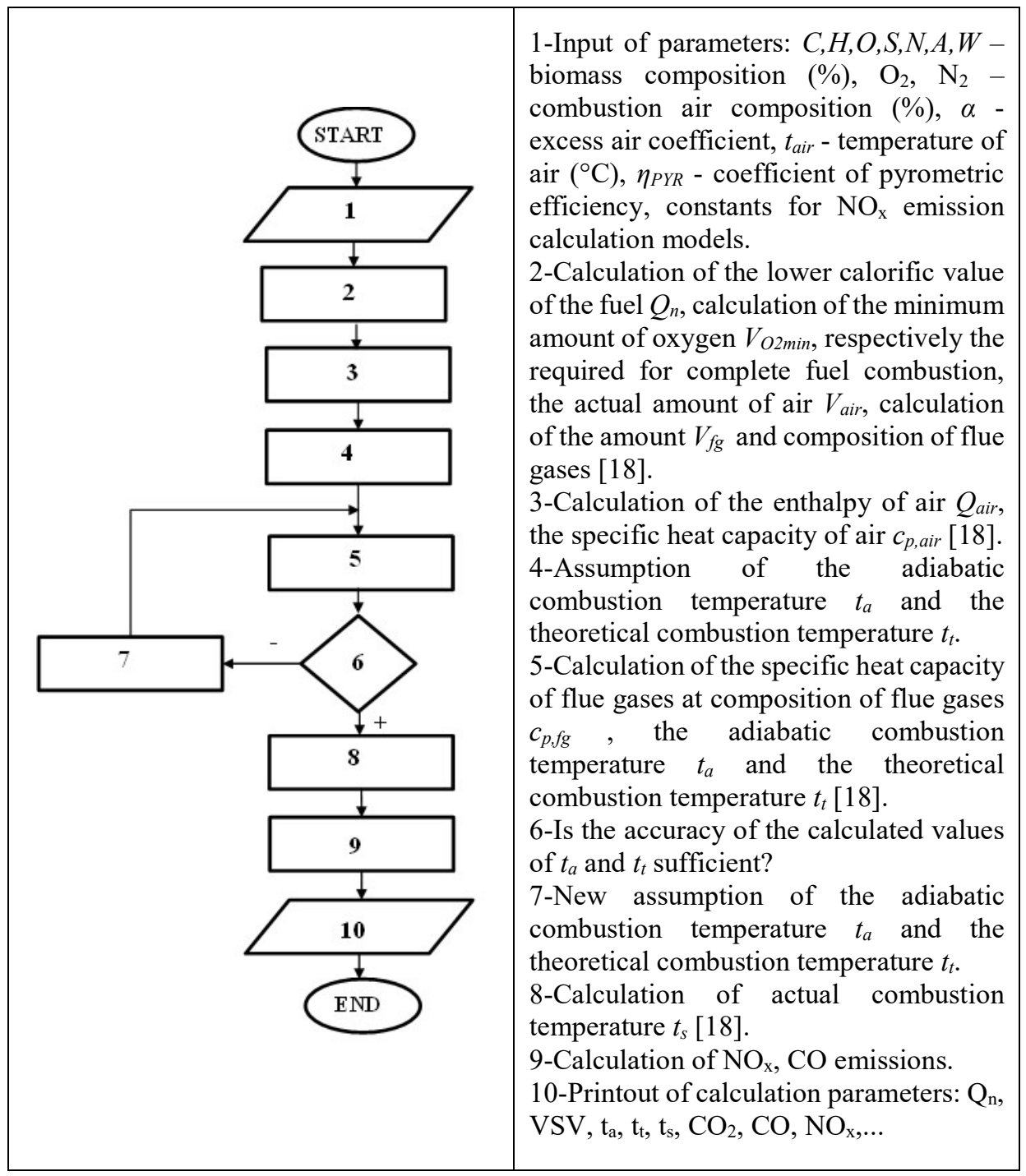

Fig. 3. Algorithm of the mathematical model. 
Input parameters of the model are the composition of the fuel and the oxidizing agent, in this case it is the air. The air parameters include the oxygen content of the combustion air, the excess air coefficient with which the fuel will be combusted, and the air temperature.

On the basis of the input data the lower calorific value of the fuel was calculated. The minimum amount of oxygen is calculated according to the minimum amount of air for combustion. In the next step, this air is recalculated to the actual amount of combustion air. The calculation of the volume of individual components of flue gases is on the basis of stoichiometry. This is followed by calculation of the adiabatic and theoretical temperature and the actual combustion temperature with the coefficient of pyrometric efficiency. At the end is the calculation of the theoretical $\mathrm{NO}_{\mathrm{x}}$ and $\mathrm{CO}$ emissions [19] and the equations are also used as determined by regression analysis based on the measured values.

The calculation procedure is shown in the Fig. 3.

\section{RESULTS AND DISCUSSION}

The wood chips was used as fuel for the boiler HERZ firematic 80 that was connected to heating system for a building. The used sample was analysed and its properties are shown in Table 1.

Table 1. The results of experimental research and computer calculations

\begin{tabular}{|c|c|c|c|c|c|c|}
\hline $\mathrm{C}$ & $\mathrm{H}$ & $\mathrm{O}$ & $\mathrm{N}$ & $\mathrm{S}$ & $\mathrm{A}$ & $\mathrm{W}$ \\
\hline $46.54 \%$ & $5.31 \%$ & $35.66 \%$ & $0.08 \%$ & $0.05 \%$ & $1.06 \%$ & $11.3 \%$ \\
\hline
\end{tabular}

The wood chips sample moisture content is shown in Table 2.

Table 2. Moisture content of wood chips

\begin{tabular}{|c|c|c|c|c|}
\hline Moisture content (\%) & $9 \%$ & $14 \%$ & $19 \%$ & $25 \%$ \\
\hline
\end{tabular}

The definition of the functional dependencies of $\mathrm{NO}_{\mathrm{x}}$ and $\mathrm{CO}$ emission generation is shown below.

The regression analysis of $\mathrm{NO}_{\mathrm{x}}$ and $\mathrm{CO}$ emission dependencies was performed for three boiler outputs $(50 \%, 75 \%, 100 \%)$ and four moisture content values of the wood chips $(9 \%, 14 \%, 19 \%, 25 \%)$. From the results of the regression analysis, functional dependencies of $\mathrm{NO}_{\mathrm{x}}$ and $\mathrm{CO}$ emissions on the moisture content of the fuel and boiler performance were obtained. Part of the measured $\mathrm{NO}_{\mathrm{x}}$ and $\mathrm{CO}$ emissions for $100 \%$ boiler output is shown in Table 3 and their graphical dependencies needed for the regression analysis are shown in Fig. 4 and Fig. 5. 
Table 3. Measured values of $\mathrm{NO}_{\mathrm{x}}$ and $\mathrm{CO}$ emissions in dependence on $100 \%$ boiler output and different fuel moisture content

\begin{tabular}{|c|c|c|}
\hline \multirow{2}{*}{\begin{tabular}{c} 
Moisture content \\
\cline { 2 - 3 }$(\%)$
\end{tabular}} & $\mathrm{NO}_{\mathrm{x}}\left(\mathrm{mg}^{-3} \mathrm{~m}^{-3}\right) 11 \% \mathrm{O}_{2}$ & $\mathrm{CO}\left(\mathrm{mg} \cdot \mathrm{m}^{-3}\right) 11 \% \mathrm{O}_{2}$ \\
\cline { 2 - 3 } & 92,31 & 1632,01 \\
\hline 9 & 228,40 & 1419,73 \\
\hline 14 & 213,19 & 1479,26 \\
\hline 19 & 74,61 & 2387,52 \\
\hline
\end{tabular}

As shown in Fig. 4, the trend line of $\mathrm{CO}$ dependence on fuel humidity and et boiler output of $100 \%$ has an increasing character with increasing moisture content.

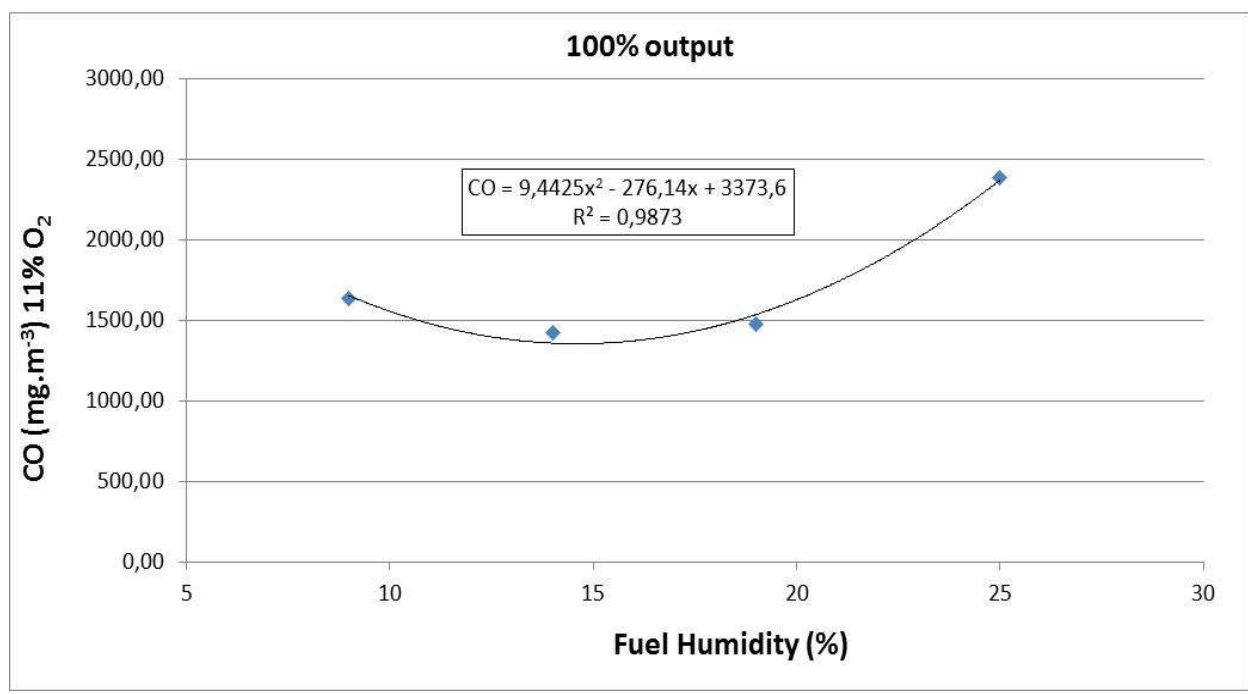

Fig. 4. Dependence of CO emission on wood chips moisture content $\%$ at $100 \%$ of boiler output with regression equation

In Fig. 5 the trend line of $\mathrm{NO}_{\mathrm{x}}$ dependence on fuel moisture content has the polynomial pattern with maximum at a moisture content between 15 and $20 \%$. The graph shows the regression equation of this dependence. 


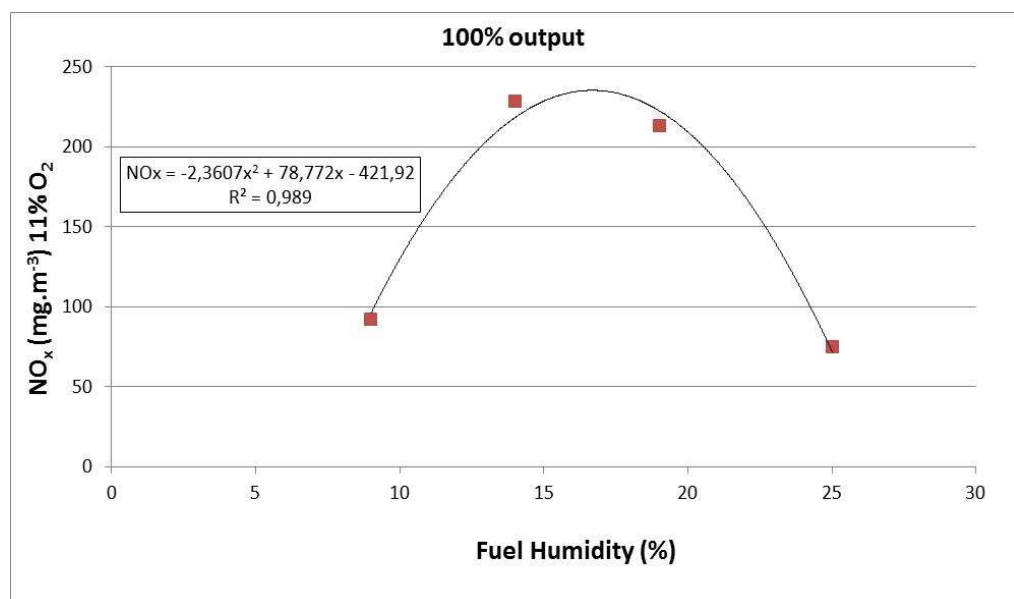

Fig. 5. Dependence of $\mathrm{NO}_{\mathrm{x}}$ emission on wood chips moisture content $\%$ at $100 \%$ of boiler output with regression equation

The measured $\mathrm{NO}_{\mathrm{x}}$ and $\mathrm{CO}$ emission values and the emissions calculated from the mathematical model are compared in the following tables Table 4 and Table 5.

Table 4 . Measured and calculated CO emission values et $100 \%$ boiler output and different values of the moisture content

\begin{tabular}{|c|c|c|}
\hline \multirow{2}{*}{$\begin{array}{c}\text { Moisture content } \\
(\%)\end{array}$} & \multicolumn{2}{|c|}{$\mathrm{CO}\left(\mathrm{mg} \cdot \mathrm{m}^{-3}\right) 11 \% \mathrm{O}_{2}$} \\
\cline { 2 - 3 } & Measured values & Calculated values \\
\hline 9 & 1632,01 & 1395,32 \\
\hline 14 & 1419,73 & 1662,59 \\
\hline 19 & 1479,26 & 1847,31 \\
\hline 25 & 2387,52 & 2013,32 \\
\hline
\end{tabular}

Table 5. Measured and calculated $\mathrm{NO}_{\mathrm{x}}$ emission values for $100 \%$ boiler output and different values of the moisture content

\begin{tabular}{|c|c|c|}
\hline \multirow{2}{*}{$\begin{array}{c}\text { Moisture content } \\
(\%)\end{array}$} & \multicolumn{2}{|c|}{$\mathrm{NO}_{\mathrm{x}}\left(\mathrm{mg} \cdot \mathrm{m}^{-3}\right)$} \\
\cline { 2 - 3 } & Measured values & Calculated values \\
\hline 9 & 92,31 & 95,81 \\
\hline 14 & 228,40 & 218,19 \\
\hline 19 & 213,19 & 222,54 \\
\hline 25 & 74,61 & 71,94 \\
\hline
\end{tabular}

It should be said that these models will never replace direct $\mathrm{NO}_{\mathrm{x}}$ measurements in practice and they only serve for quick verification of the amount of nitrogen oxides produced. 


\section{CONCLUSION}

Responsible behavior in the energy sector means rational and efficient use of energy of all available energy sources. The use of biomass for energy production reduces transport costs, provides a renewable energy source and reduces $\mathrm{CO}_{2}$ emissions. The recommended relations for the calculation of the production of nitric oxides, carbon monoxide and carbon dioxide presented in this paper have a more universal application and simpler form of expression than the currently used models.

The presented mathematical model for determination of $\mathrm{NO}_{\mathrm{x}}$ and $\mathrm{CO}$ emissions production during combustion is based on selected physical quantities and can be used in combustion devices where the parameters of the combustion process can be measured.

This will make it possible to use the developed model even in real terms. Based on the results of the mathematical model, the boiler operator can manage its operation efficiently in terms of its fuel efficiency and humidity.

The results of the effect of power, moisture content of wood chips and excess of combustion air will help cleaner operation to reduce undesirable emissions.

Due to the complexity of an exact description of the process of pollutant formation as well as different combustion conditions, it is not possible to draw up a generally valid model that would describe this production for various types of boilers and different types and forms of fuels.

\section{ACKNOWLEDGEMENTS}

This publication is the result of the Project implementation: Research centre for efficient integration of the renewable energy sources (VUKONZE), ITMS: 26220220064 supported by the Research \& Development Operational Programme funded by the ERDF.

\section{REFERENCES}

1. Shirneshan, A and Jamalvand, H 2016. Modeling Gaseous Emissions from Peat (Biomass) and Diesel Fuels Combustion, Energy and Environment Focus, 5, 1, 70-76.

2. Zhou, H, Jensen, AD, Glarborg, P, Jensen, PA and Kavaliauskas, A 2005. Numerical modeling of straw combustion in a fixed bed. Fuel 84 389-403.

3. Zhou, H, Jensen, AD, Glarborg, P and Kavaliauskas, A 2006. Formation and reduction of nitric oxide in fixed-bed combustion of straw. Fuel 85, 705-716.

4. Wei, Zhao, Zhengqi, Li, Dawei, Wang, Qunyi, Zhu, Rui, Sun, Baihong, Meng and Guangbo, Zhao 2008. Combustion characteristics of diferent parts of corn 
straw and NO formation in a fixed bed, Bioresource Technology 99, 29562963.

5. Holubčik, M, Kantová, N, Červenka, B and Trnka, J 2019. Mathematic model for prediction of heat output of small boiler depending on various aspects, AIP Conference Proceedings 2118, 030015.

6. Vlček, J, Velička M, Jančar, D, Burda, J and Blahůšková V 2016. Modelling of thermal processes at waste incineration, Energy Sources, Part A: Recovery, Utilization, and Environmental Effects, 38:23, 3527-3533.

7. Dzurenda, L 2017. 3D diagram of heat boiler efficiency for combustion of fuelwood, Acta Facultatis Xylologiae Zvolen, 59, 1, 149-156.

8. Vitázek, I, Klúčik, J, Mikulová, Z and Vereš, P 2016. Effects on Concentration of Selected Gaseous Emissions at Biomass Combustion, in Proc. of the 35th Meeting of Departments of Fluid Mechanics and Thermomechanics (MDFMT), Samorin, Slovakia, 020022-1-020022-11.

9. Dzurenda, L, Hroncová, E and Ladomerský, J 2017. Extensive Operating Experiments on the Conversion of Fuel-Bound Nitrogen into Nitrogen Oxides in the Combustion of Wood Fuel. Forests 8, 1.

10. Salzmann, R and Nussbaumer, T 2001. Fuel staging for NOx reduction in biomass combustion: Experiments and modelling. Energy Fuels, 15, 575582.

11. Fournel, S, Marcos, B, Godbout, S and Heitz M 2015. Predicting gaseous emissions from small-scale combustion of agricultural biomass fuels. Bioresour. Technol. 179, 165-172.

12. Rimár, M and Fedák, M 2014. Combustion processes (In Slovak: Spal'ovacie procesy), 1st ed. Prešov: Technical University of Košice, p.144.

13. Wang, K, Nakao, S, Thimmaiah, D and Hopke PK 2019. Emissions from inuse residential wood pellet boilers and potential emissions savings using thermal storage, 676, 564-576.

14. Rimár, M, Fedák, M, Korshunov, A, Kulikov, A and Mižáková J 2016. Determination of excess air ratio during combustion of wood chips respect to moisture content, Acta Facultatis Xylologiae Zvolen, 58, 2,133-140.

15. Hrdlicka, J, Skopec, P, Dlouhy, T and Hrdlicka, F 2016. Emission factors of gaseous pollutants from small scale combustion of biofuels, Fuel, 165, 6874.

16. Durdán, M and Kostúr, K 2015. Modeling of temperatures by using the algorithm of queue burning movement in the UCG Process, Acta Montanistica Slovaca, 20, 3,181-191.

17. Variny, M and Mierka, O 2018. Boiler performance and combusted biomass quality control improvement in an industrial biomass boiler, Waste Forum, 3, 346-358. 
18. Varga, A, Jablonský, G, Lukáč, L and Kizek, J 2013. Thermal technology for metallurgists (In Slovak: Tepelná technika pre hutníkov), Technical University of Košice, Faculty of Metallurgy, 280.

19. Jandačka, J, Malcho, M and Mikulík, M 2008. Ekologické aspekty zámeny fosilnych paliv za biomasu, Publisher Jozef Bulejčík, Mojš, 226.

Editor received the manuscript: 24.06.2019 